\title{
Enhanced bactericidal activity of silver thin films deposited via aerosol-assisted chemical vapour deposition
}

Sapna D. Ponja, ${ }^{a}$ Sandeep K. Sehmi, ${ }^{a, b, c}$ Elaine Allan, ${ }^{c}$ Alexander J. MacRobert, ${ }^{b}$ Ivan P. Parkin ${ }^{a}$ and Claire J. Carmalt ${ }^{a}$.

${ }^{a}$ Materials Chemistry Research Centre, Department of Chemistry, University College London, 20 Gordon Street, London, WC1H 0AJ, UK. E-mail: c.j.carmalt@ucl.ac.uk

${ }^{b}$ UCL Division of Surgery and Interventional Science, University College London, 67-73 Riding House Street, London, W1 W7EJ, UK.

${ }^{c}$ Division of Microbial Disease, UCL Eastman Dental Institute, University College London, 256 Gray's Inn Road, London, WC1X 8LD, UK.

*correspondence author

Keywords: Antimicrobial, Escherichia coli, Staphylococcus aureus, CVD, Ag, FTO

\section{Abstract}

Silver thin films were deposited on $\mathrm{SiO}_{2}$ barrier coated float glass, fluorine-doped tin oxide (FTO) glass, Activ ${ }^{\mathrm{TM}}$ glass and on a $\mathrm{TiO}_{2}$ coated float glass via AACVD using silver nitrate at $350{ }^{\circ} \mathrm{C}$. The films were annealed at $600{ }^{\circ} \mathrm{C}$ and analysed by X-ray powder diffraction (XRD), X-ray photoelectron spectroscopy (XPS), UV/Vis/Near IR spectroscopy and scanning electron microscopy (SEM). All the films were crystalline and the silver was present in its elemental form and of nanometre dimension. The antibacterial activity of these samples was tested against Escherichia coli and Staphylococcus aureus in the dark and under UV light $(365 \mathrm{~nm})$. All Ag-deposited films reduced the numbers of $E$. coli by $99.9 \%$ within 6 hours and the numbers of $S$. aureus by $99.9 \%$ within only 2 hours. FTO/Ag reduced bacterial numbers of $E$. coli to below the detection limit after 60 minutes and caused a $99.9 \%$ reduction of $S$. aureus within only 15 minutes of UV irradiation. Activ ${ }^{\mathrm{TM}} / \mathrm{Ag}$ reduced the numbers of S. aureus by $66.6 \%$ after 60 minutes and $\mathrm{TiO}_{2} / \mathrm{Ag}$ killed $99.9 \%$ of $S$. aureus within 60 minutes of UV exposure. More remarkably, we observed a $99.9 \%$ reduction in the numbers of $E$. coli within 6 hours and the numbers of $S$. aureus within 4 hours in the dark using our novel $\mathrm{TiO}_{2} / \mathrm{Ag}$ system.

\section{Introduction}

Significant progress has been made in recent years in tracking healthcare-acquired infections (HCAI), however, there are still many gaps in our knowledge regarding these often life-threatening infections. ${ }^{1}$ In order to develop new methods to prevent HCAls and preserve available antibiotics, we need to evaluate current methods and find new ways of preventing infection. ${ }^{2}$ Whilst the incidence 
of superbug outbreaks due to Clostridium difficile (C. difficile) and methicillin-resistant Staphylococcus aureus (MRSA) appear to have fallen in the last few years in some European countries, new multiply resistant Gram-negative bacterial pathogens have emerged. ${ }^{3}$ In particular, a family of Gram-negative bacteria known as Enterobacteriaceae (such as E. coli and Klebsiella spp.), which are normally found in the human intestine, are an increasing global problem with strains exhibiting multiple antibiotic resistance. ${ }^{4}$

Several control measures can be implemented to reduce HCAls, such as patient isolation with appropriate ventilation, improvements in hand washing and using disposable devices and equipment. Furthermore, regular and effective cleaning of hospitals is also required, however, rather than killing bacterial pathogens in the hospital environment, ineffective cleaning may simply spread them around. ${ }^{5}$ An alternative approach is to use self-sterilising surfaces in hospitals that do not require regular cleaning to efficiently reduce the load of bacteria associated with HCAls. ${ }^{6-8}$

Silver thin films have long been considered of interest in applications such as microelectronics, high temperature superconducting ceramics, silver mirrors and bactericidal coatings. ${ }^{9-10}$ The mechanism of antibacterial activity of silver films or nanoparticles involves denaturation of cell wall proteins and a consequent decrease in growth rate. ${ }^{11}$ Silver ions can be involved in catalytic oxidation reactions between oxygen molecules in cells and hydrogen atoms in thiol groups (forming disulfide bonds through covalent bonding) and lead to blocking of respiration and bacterial cell death. ${ }^{12}$ Furthermore, silver nanoparticles can also damage the cell membranes of bacteria by the formation of free radicals. ${ }^{13}$

A variety of methods have been employed to deposit silver films on surfaces including electrostatic deposition, sputtering and evaporation, but the majority of reports have used some form of chemical vapour deposition (e.g., super critical fluid transport, ${ }^{14}$ metal organic, ${ }^{15}$ low pressure ${ }^{10}$ and aerosol-assisted $\left.{ }^{10,16}\right)$. The deposition of silver thin film via CVD has been greatly hampered by the lack of precursors that are stable (most are air and moisture sensitive), volatile ${ }^{9}$ and readily available. Precursors previously used include silver halides and carboxylates, organophosphine adducts of silver and more extensively $\beta$-diketonates or related mono-thio- $\beta$-diketonates and $\beta$ diketiminate. ${ }^{10}$ These complexes require multi-step synthesis and need to be assessed for their suitability as precursors prior to film deposition ${ }^{17-18}$ which can be challenging since they need to have a high vapour pressure as well as react on a heated substrate. ${ }^{16}$ Aerosol-assisted CVD (AACVD) is a proven technique for the deposition of films using precursors that are not necessarily volatile and/or thermally stable but only that they are soluble. ${ }^{19-21}$ Furthermore, depositions do not require high 
pressures and the greater availability of precursors allows more flexibility of the properties of the film makes the technique more versatile and low cost. ${ }^{19,22-23}$

In this paper, we demonstrate the antibacterial activity of silver thin films deposited via AACVD on float glass ( $\mathrm{SiO}_{2}$ barrier coated), fluorine-doped tin oxide (FTO) glass and Activ ${ }^{\mathrm{TM}}$ glass (15 $\mathrm{nm}$ thick $\mathrm{TiO}_{2}$ anatase layer) when activated by $365 \mathrm{~nm}$ UV radiation. In addition, a $\mathrm{TiO}_{2} / \mathrm{Ag}$ film was deposited on float glass for comparison with Pilkington NSG Activ ${ }^{\mathrm{TM}}$ glass. To our knowledge this is the first deposition of silver films by AACVD on different substrates. We show that these robust films can be easily made by an efficient up-scalable technique. $\mathrm{TiO}_{2}$ is a well-known photocatalytic agent that has been extensively used for destroying microorganisms including bacteria, viruses and fungi. ${ }^{24}$ These self-sterilising films have potential applications in hospital and other environments where bacterial contamination is problematic, e.g., food processing facilities. Furthermore, the development of metal-modified $\mathrm{TiO}_{2}$ coatings can enhance the antibacterial activity rendering these films antibacterial even in the dark.

\section{Experimental}

Deposition method. Depositions were carried out in a nitrogen atmosphere (99.99\%, BOC). The glass substrates $(15 \mathrm{~cm} \times 4 \mathrm{~cm} \times 0.3 \mathrm{~cm})$ used were obtained from Pilkington Ltd (UK): $\mathrm{SiO}_{2}$ barrier coated float (ca. $50 \mathrm{~nm}$ thickness; the coating prevents the ions within the glass diffusing to the surface), fluorine-doped tin oxide (FTO) and Activ $^{\mathrm{TM}}$. The substrates were cleaned with detergent, propan-2-ol and acetone to remove surface grease. The precursor solution consisting of $0.50 \mathrm{~g}$ of silver nitrate (purchased from Sigma-Aldrich) in a 1:5 water to methanol ratio was placed in a glass bubbler. An aerosol was generated using a piezo electric device and carried, in a flow of nitrogen (1 $\mathrm{L} / \mathrm{min})$, through into horizontal bed cold-walled reactor $(15 \mathrm{~cm} \times 5 \mathrm{~cm})$. The glass substrate, placed on the top and bottom of the reactor, was preheated to $350{ }^{\circ} \mathrm{C}$ on a graphite block containing a Whatman cartridge heater monitored by a Pt-Rh thermocouple. The gap between the top and bottom substrate was $0.5 \mathrm{~cm}$ to ensure a laminar flow and the top substrate was $50-70{ }^{\circ} \mathrm{C}$ cooler than the heated bottom glass substrate. Depositions were achieved by the aerosol being carried in a stream of nitrogen through a brass baffle into the reactor. Waste vapours were eliminated through the exhaust. Once the entire precursor solution had been used up the reactor was allowed to cool to room temperature under nitrogen. The films were deposited on the top substrate most likely a result of thermophoresis whereby the particles are unable to diffuse through the diffusion layer at the heated substrate and rebound to adsorb to the top surface. ${ }^{25}$ Complete coverage of the substrate was achieved and the films were solvent annealed with methanol at $600{ }^{\circ} \mathrm{C}$ under nitrogen $(0.5 \mathrm{~L} / \mathrm{min})$ for 2 hours. 
A $\mathrm{TiO}_{2}$ film was deposited onto $\mathrm{SiO}_{2}$ barrier float glass. The precursor solution consisted of $0.50 \mathrm{~g}$ of titanium ethoxide (purchased from Sigma-Aldrich) in $15 \mathrm{~mL}$ of toluene (purchased from VWR). The deposition was carried out at $500{ }^{\circ} \mathrm{C}$ under a flow rate of $1.0 \mathrm{~L} / \mathrm{min}$ nitrogen. The $\mathrm{TiO}_{2} / \mathrm{Ag}$ film was produced by first depositing $\mathrm{TiO}_{2}$ followed by the deposition of silver as described above. Following the deposition of silver, the film was annealed in the same way as the other silver films.

Film analysis. X-ray diffraction (XRD) measurements were obtained using a modified Bruker-Axs D8 diffractometer with parallel beam optics fitted with a PSD LynxEye silicon strip detector to collect diffracted X-ray photons. X-rays were generated using a Cu source with $\mathrm{Cu} \mathrm{K} \alpha 1$ and $\mathrm{Cu} \mathrm{K} \alpha 2$ radiation of wavelengths 1.54056 and $1.54439 \AA$, respectively, with an intensity ratio of 2:1 and at $40 \mathrm{kV}$ and $30 \mathrm{~mA}$. The incident beam angle was kept at $1^{\circ}$, and the angular range of the patterns collected was $10^{\circ}<2 \theta<66^{\circ}$ with a step size of $0.05^{\circ}$ counted at $0.5 \mathrm{~s} / \mathrm{step}$. The patterns were analysed for crystallinity and preferred orientation. Peak positions were compared to patterns from the Inorganic Crystal Structure Database (ICDS).

X-ray photoelectron spectroscopy (XPS) analysis of the films was carried out using a Thermo Scientific K-Alpha spectrometer equipped with a monochromatic Al-Ka source to identify chemical constituents. The peaks were modelled using CasaXPS software with binding energies adjusted to adventitious carbon (284.5 eV) in order to compensate for the effects of charging. Survey scans were collected in the range $0-1350 \mathrm{eV}$ (binding energy) at a pass energy of $40 \mathrm{eV}$.

UV/Vis/Near IR transmittance and reflectance spectra were produced using the Perkin Elmer Precisely Lambda 950 spectrometer using an air background and recorded between 320-2500 nm.

Scanning electron microscopy (SEM) was used to determine the film morphology from a top-down configuration using a JEOL JSM-6301F Field Emission instrument with accelerating voltages ranging from 3-5 keV on Au-coated samples.

Antibacterial activity. The films were cut into $1 \mathrm{~cm}^{2}$ sections to evaluate their antibacterial activity. The following samples were tested: float glass $\left(\mathrm{Ag}, \mathrm{TiO}_{2}\right.$ and $\left.\mathrm{TiO}_{2} / \mathrm{Ag}\right)$, and $\mathrm{Ag}$ on $\mathrm{Activ}^{\mathrm{TM}}$ and $\mathrm{FTO}$. Comparisons were made against the same substrate without modification. The antibacterial activity of these samples were tested against Escherichia coli strain ATCC 25922 and Staphylococcus aureus 8325-4, which were stored at $-70{ }^{\circ} \mathrm{C}$ in Brain-Heart-Infusion broth (BHI, Oxoid) containing $20 \%(\mathrm{v} / \mathrm{v}$ ) glycerol and propagated onto MacConkey agar (MAC, Oxoid) for samples exposed to E. coli, or Mannitol Salt agar (MSA, Oxoid) for samples exposed to $S$. aureus, for a maximum of two subcultures at intervals of 2 weeks. 
$\mathrm{BHI}$ broth was inoculated with one bacterial colony and cultured in air at $37{ }^{\circ} \mathrm{C}$ for 18 hours with shaking, at $200 \mathrm{rpm}$. The bacterial pellet was recovered by centrifugation $\left(20^{\circ} \mathrm{C}, 2867.2 \mathrm{~g}, 5 \mathrm{~min}\right)$, washed in PBS $(10 \mathrm{~mL})$, centrifuged again to recover the pellet $\left(20^{\circ} \mathrm{C}, 2867.2 \mathrm{~g}, 5 \mathrm{~min}\right)$, and the bacteria were finally re-suspended in PBS $(10 \mathrm{~mL})$. The washed suspension was diluted 1000 -fold to obtain an inoculum of $\sim 10^{6} \mathrm{cfu} / \mathrm{mL}$. In each experiment, the inoculum was confirmed by plating 10 fold serial dilutions on agar for viable counts. $25 \mu \mathrm{L}$ of the inoculum was spread evenly on the surface of each sample in duplicate. The samples were then irradiated for up to 6 hours at room temperature using UVA (Vilber-Lourmat, $2 \times 8 \mathrm{~W}, 365 \mathrm{~nm}, 0.65 \pm 0.23 \mathrm{~mW} \mathrm{~cm}^{-2}$ ) radiation and incubated under dark conditions for the same duration. Prior to inoculation, all the samples were sterilised by pre-irradiation overnight using a $365 \mathrm{~nm}$ UV light.

Post incubation, the inoculated samples were added to PBS $(450 \mu \mathrm{L})$ and mixed thoroughly using a vortex mixer (20 s). The neat suspension and 10-fold serial dilutions were plated on agar for viable counts $(100 \mu \mathrm{L})$. The plates were inoculated aerobically at $37{ }^{\circ} \mathrm{C}$ for 24 hours. Each experiment contained a minimum of two technical replicates and the experiment was repeated three times. The statistical significance of the following comparisons in both the light and dark conditions was analysed using the Mann-Whitney $U$ test: (i) blank glass vs. inoculum; (ii) $\mathrm{TiO}_{2}$ alone vs glass; (iii) $\mathrm{TiO}_{2} / \mathrm{Ag}$ vs $\mathrm{TiO}_{2}$ alone; (iv) $\mathrm{TiO}_{2} / \mathrm{Ag}$ vs Ag alone; (v) Ag alone vs glass or $\mathrm{Activ}^{\mathrm{TM}}$ or FTO.

\section{Result and Discussion}

\section{Analysis of films}

Silver thin films were deposited via AACVD using silver nitrate in a water/methanol solvent mixture at $350{ }^{\circ} \mathrm{C}$ under a flow of $\mathrm{N}_{2}$. Films were deposited on $\mathrm{SiO}_{2}$ barrier coated float glass, fluorine-doped tin oxide (FTO) glass, Activ ${ }^{\top \mathrm{M}}$ glass and on a $\mathrm{TiO}_{2}$ coated float glass. $\mathrm{TiO}_{2}$ was deposited using titanium ethoxide in a toluene solution at $500{ }^{\circ} \mathrm{C}$ under a flow of $\mathrm{N}_{2}$. The resulting films achieved complete coverage and were subsequently annealed at $600{ }^{\circ} \mathrm{C}$ in $\mathrm{N}_{2}$ for 2 hours before spectroscopic analysis and evaluation of antimicrobial activity.

XRD showed that all films were crystalline (Fig. 1). The patterns for the silver films confirmed the presence of bulk silver exhibiting reflections in the (111), (200) and (220) planes at 38.1, 44.3 and $64.52 \theta$ values, respectively, matching well with the standard pattern. Moreover, it was found that the pure Ag films were grown regardless of the substrate indicating that the substrates had no influence on the crystallographic phase as expected.

The $\mathrm{TiO}_{2}$ pattern has a few suppressed peaks ((103), (004), (112), (105) and (213)) when compared with the standard pattern which suggests that the AACVD grown $\mathrm{TiO}_{2}$ film has some profound 
preferred orientation. $\mathrm{TiO}_{2}$ was matched to the anatase phase having reflections corresponding to the (101), (200), (211) and (204) planes. However, previous $\mathrm{TiO}_{2}$ thin films grown via AACVD using titanium tetra-isopropoxide in an ethyl acetate solution at $450{ }^{\circ} \mathrm{C}$ only showed reflections in the (101), (112) and (211) planes. ${ }^{22}$ Hence, deposition conditions such as the temperature and the solvent used have a significant effect on preferential orientation of films grown via AACVD. No peaks corresponding to the $\mathrm{TiO}_{2}$ component were observed from the pattern obtained for Activ $^{\mathrm{TM}} / \mathrm{Ag}$ composite due to the thickness of the Ag layer masking the very thin $(15 \mathrm{~nm})$ anatase layer of Activ $^{\top M}$ glass. An estimation of the crystallite size that was derived from the XRD data using the Scherrer equation ${ }^{26}$ showed the Ag crystallites to be between $30-40 \mathrm{~nm}$ and independent of substrate. The AACVD grown $\mathrm{TiO}_{2}$ film had a similar crystallite size (ca. $30 \mathrm{~nm}$ ).

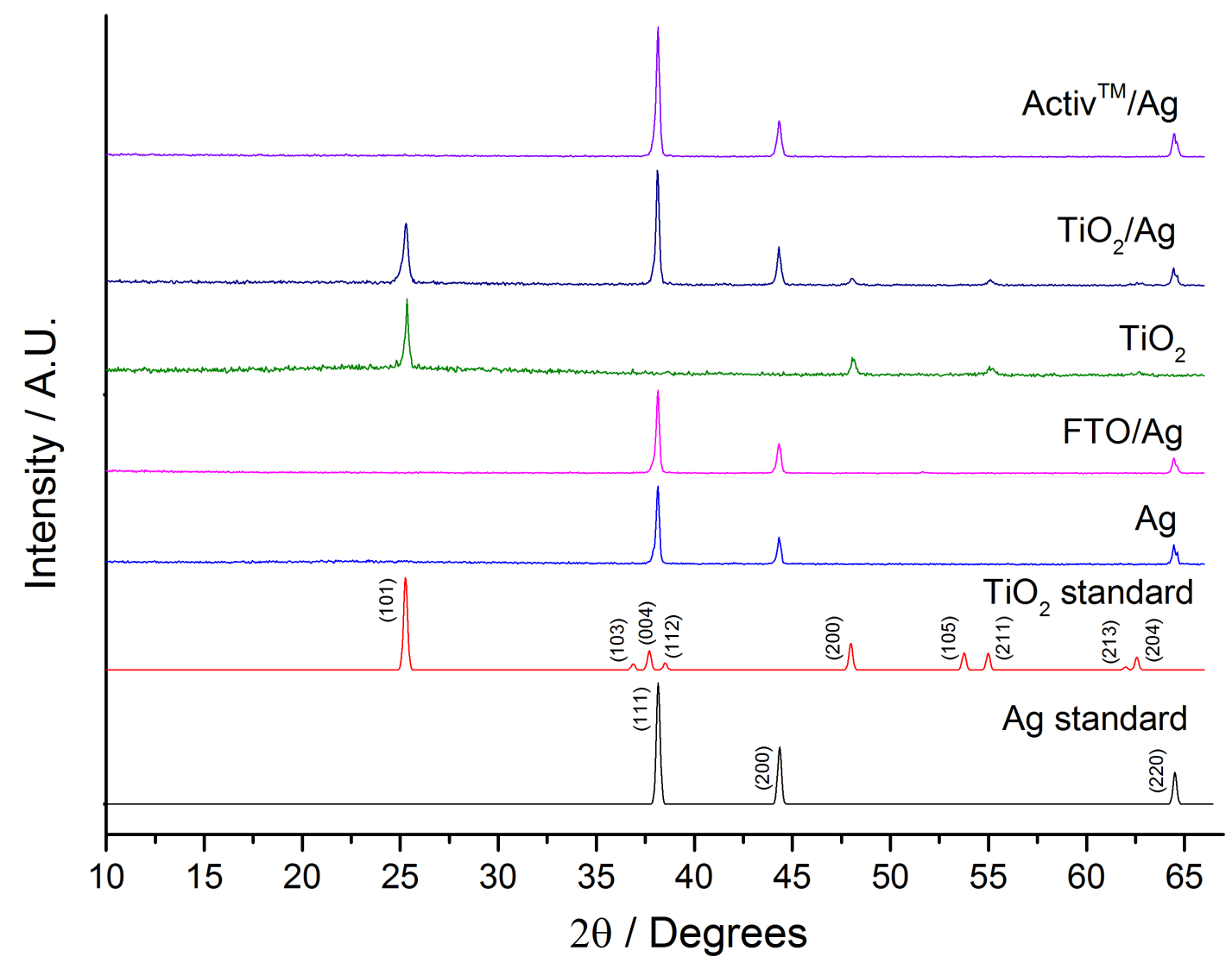

Fig. 1. XRD patterns for the standards ${ }^{27-28}$ and for the films deposited on various substrates using AACVD. $\mathrm{TiO}_{2}$ was deposited at $500{ }^{\circ} \mathrm{C}$ using titanium ethoxide in toluene. The silver films were deposited at $350{ }^{\circ} \mathrm{C}$ from silver nitrate in a $1: 5$ water to methanol solution.

Although the XPS binding energies of $\mathrm{Ag}$ and $\mathrm{Ag}_{2} \mathrm{O}$ are similar, ${ }^{29}$ it would not be unreasonable to assume, in light of the XRD patterns, that only $\mathrm{Ag}$ is present (Fig. 2) with no $\mathrm{Ag}_{2} \mathrm{O}$ contamination. This is advantageous as it shows that there is no detectable surface oxidation, hence maximising the 
surface area of silver available for antimicrobial activity. The binding energy of the $3 d_{5 / 2}$ peak were $368.3,368.3,368.4$ and $368.3 \mathrm{eV}$ for $\mathrm{Ag}$ on float glass, $\mathrm{FTO}$, Activ ${ }^{\mathrm{TM}}$ and $\mathrm{TiO}_{2}$, respectively. These values are in close agreement with that reported in the literature: $368.4 \mathrm{eV} .^{30}$ The binding energy of the $\mathrm{Ti} 2 \mathrm{p}_{3 / 2}$ was at $458.3 \mathrm{eV}$ and $458.9 \mathrm{eV}$ for $\mathrm{TiO}_{2}$ and $\mathrm{TiO}_{2} / \mathrm{Ag}$, respectively, corresponding to $\mathrm{Ti}^{4+}{ }^{22}$

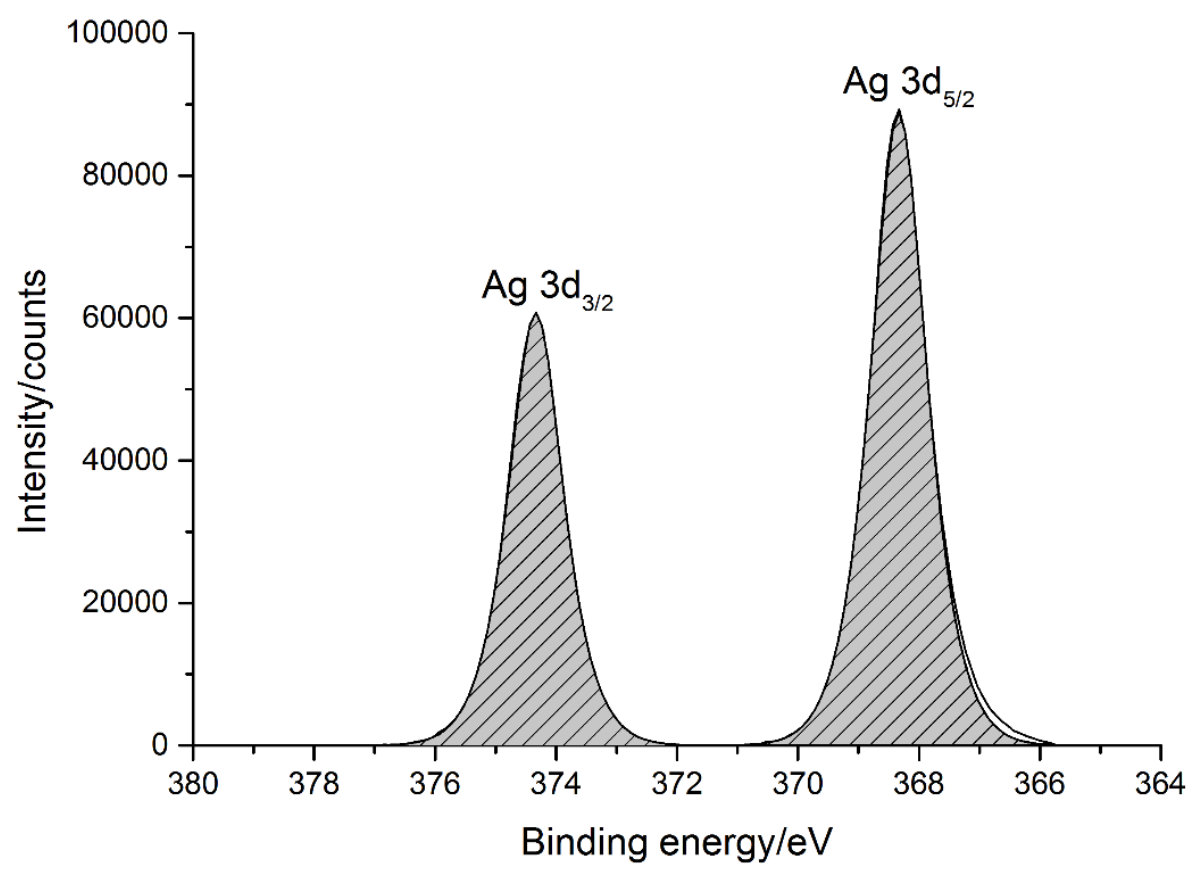

Fig. 2. XPS of silver deposited on $\mathrm{SiO}_{2}$-barrier coated float glass showing binding energies for the $\mathrm{Ag}^{0}$ state. 
(a)

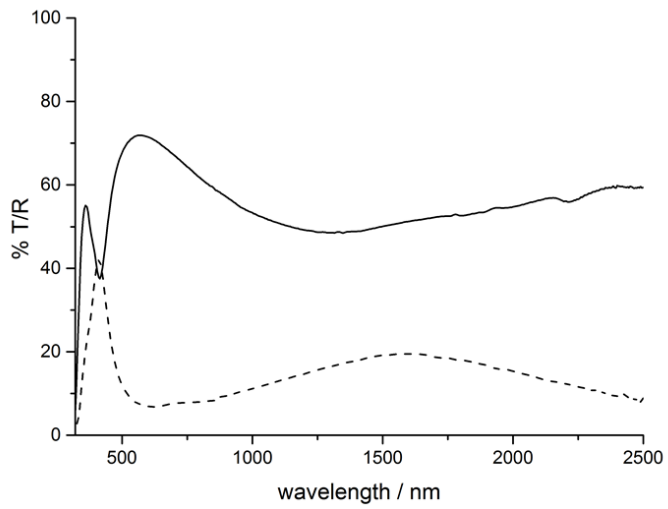

(c)

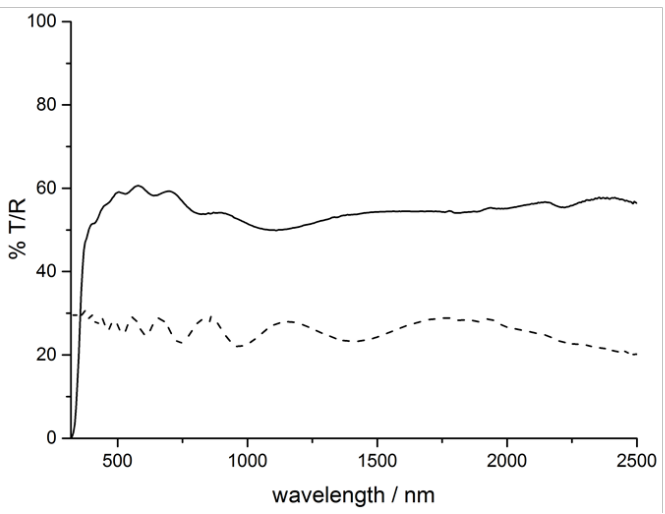

(b)

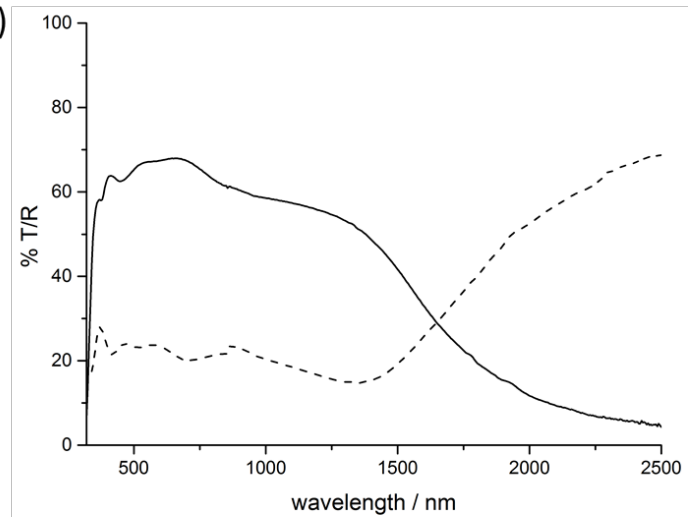

(d)

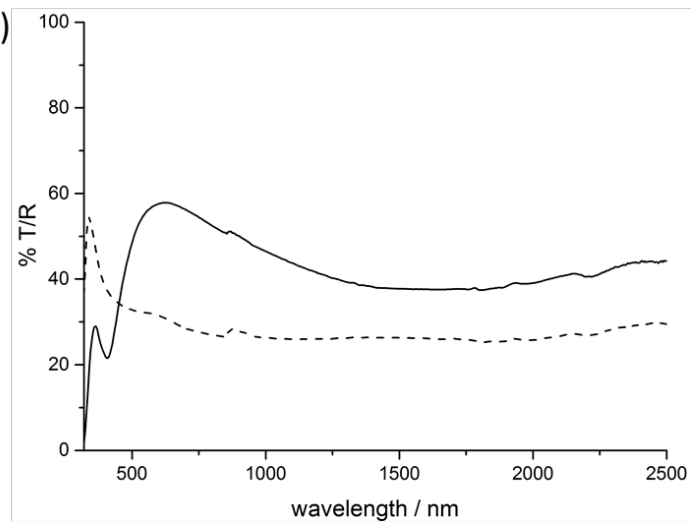

Fig. 3. The transmittance (-) and reflectance (---) properties of the Ag films deposited via AACVD on to different glass substrates using silver nitrate in a $1: 5$ water to methanol solution at $350{ }^{\circ} \mathrm{C}$. (a) $\mathrm{SiO}_{2}$ barrier coated float; (b) FTO; (c) $\mathrm{TiO}_{2}$ and (d) Activ $^{\mathrm{TM}}$.

The transmission and reflectance properties of the films were investigated using UV-vis spectroscopy. The greatest transparency $(\sim 70 \%)$ was observed with Ag deposited on float glass followed closely by Ag on FTO glass. However, the latter had more than twice the reflectance. The silver coated Activ $^{\mathrm{TM}}$ film exhibited the greatest reflectance ( $\left.30 \%\right)$.

In an effort to correlate light absorption to antibacterial activity, the absorbance of Ag films at 365 $\mathrm{nm}$ was determined from UV-vis data. The results indicated similar absorbance values for $\mathrm{Ag}$ deposited on float glass, $\mathrm{TiO}_{2}$ and Activ $^{\mathrm{TM}}$ of 26,29 and 24\%, respectively. These are almost double the absorbance value obtained for Ag deposited on FTO glass, suggesting a lower antibacterial activity after $365 \mathrm{~nm}$ UV activation in comparison to other Ag films. However, Ag on FTO glass was found to have potent bactericidal effects against E. coli and S. aureus (see table 1 and 2).

Figure 4 shows the scanning electron microscope images of the Ag films on different glass substrates: (a) float, (b) FTO, (c) $\mathrm{TiO}_{2}$ and (d) $\mathrm{Activ}^{\mathrm{TM}}$. In general, the particles on the substrates adopt a spherical morphology and are well distributed apart from Ag on FTO, where they appear as if they have coalesced together to form non-spherical entities that are sparsely distributed. Other AACVD studies, which have deposited silver films using different precursors and deposition conditions, have 
also observed spherical particles. ${ }^{31-32}$ The particles on FTO are much larger at an average width of 7 $\mu \mathrm{m}$ than those found on the other substrates. On float glass and $\mathrm{Activ}^{\top \mathrm{M}}$ the particle sizes vary from a few nanometres to roughly $1.5 \mu \mathrm{m}$ and $750 \mathrm{~nm}$ in diameter, respectively. However, on the AACVD deposited $\mathrm{TiO}_{2}$ substrate the $\mathrm{Ag}$ particles are even smaller, ranging from a few nanometres to 500 $\mathrm{nm}$. This coupled with the dense distribution (substrate almost entirely covered) leads to the exposed Ag surface area on the $\mathrm{TiO}_{2}$ substrate being the highest. Hence this could be responsible for the enhanced antimicrobial activity (see below) observed on $\mathrm{TiO}_{2}$ compared to the other substrates.

It is important to note that the particles observed via SEM are made up of a collection of $\mathrm{Ag}$ crystallites and hence are of a much larger size than the crystallite sizes estimated by the Scherrer equation.
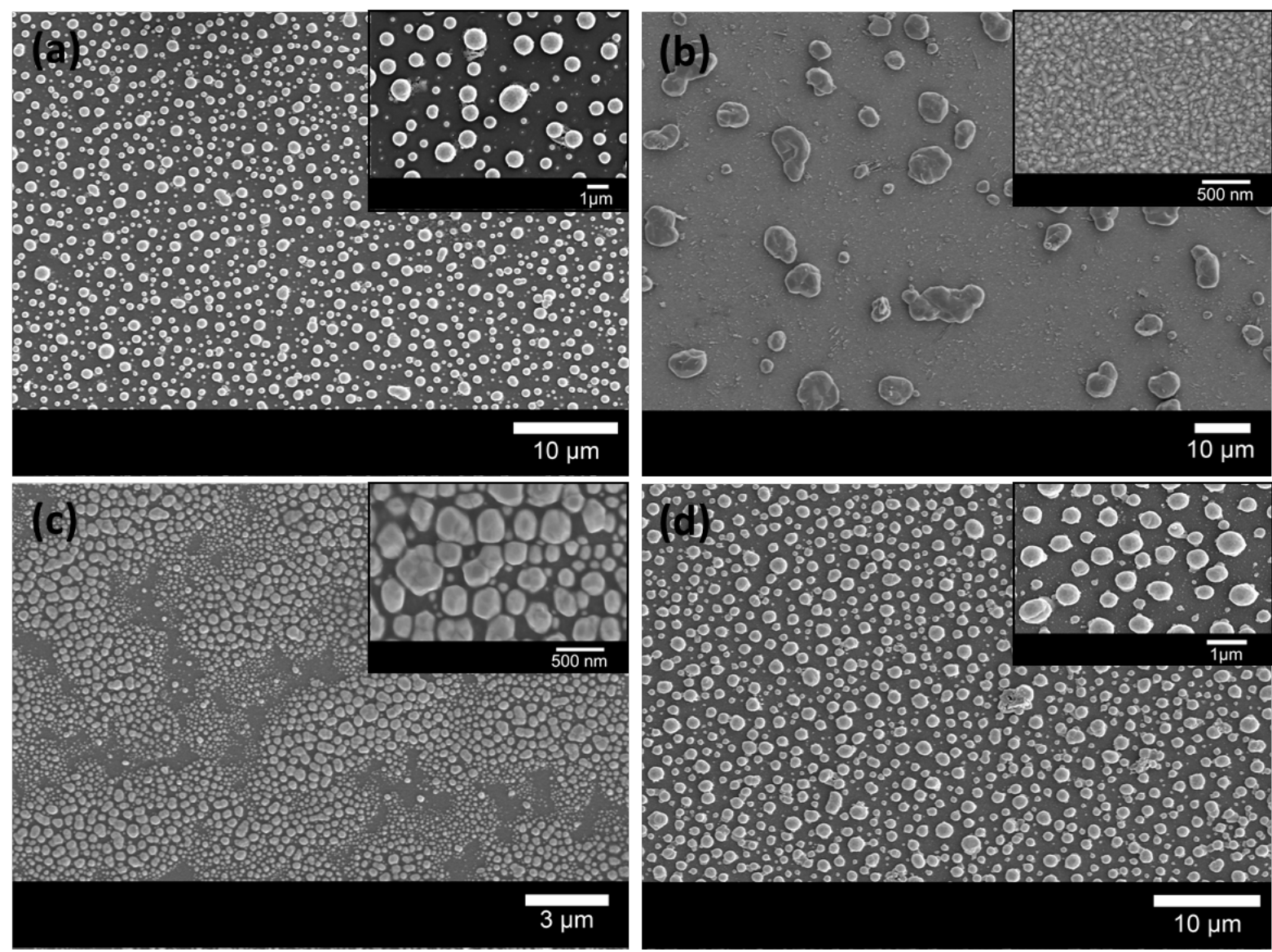

Fig. 4. SEM images showing the morphologies of the films grown on various glass substrates via AACVD at $350{ }^{\circ} \mathrm{C}$ using silver nitrate in a $1: 5$ water to methanol solution (a) $\mathrm{SiO}_{2}$ barrier coated float; (b) FTO; (c) $\mathrm{TiO}_{2}$ and (d) Activ ${ }^{\mathrm{TM}}$.

\section{Antibacterial activity}

The antibacterial activity of $\mathrm{TiO}_{2}$ and $\mathrm{Ag}$ thin films on various substrates was tested against $E$. coli, as a representative Gram-negative bacterium and S. aureus, as a representative Gram-positive 
bacterium. The antibacterial activity was tested using a $365 \mathrm{~nm}$ UV light source and the same samples were examined in the dark as a control.

Fig. 5 demonstrates the antibacterial activity of various samples tested in the dark against $E$. coli in 6 hours. Float, $\mathrm{FTO}, \mathrm{TiO}_{2}$ and $\mathrm{Activ}^{\mathrm{TM}}$ glass did not display any significant antibacterial activity. FTO/Ag and $\mathrm{Ag}$ films produced $\sim 1-1.5$ log reduction in bacterial numbers $(P=0.001)$. The $\mathrm{TiO}_{2} / \mathrm{Ag}$ film resulted in the greatest kill showing a $99.9 \%$ reduction in the numbers of bacteria $(\sim 3 \log ; P=0.001)$ following 6 hours of incubation in the dark whereas Activ $^{\mathrm{TM}} / \mathrm{Ag}$ produced a $\sim 50 \%$ reduction in bacterial numbers $(\mathrm{P}=0.001)$. Thus, there is a large difference in the effect of $\mathrm{Ag}$ deposited on $\mathrm{TiO}_{2}$ compared with Ag on Activ $^{\top \mathrm{M}}$.

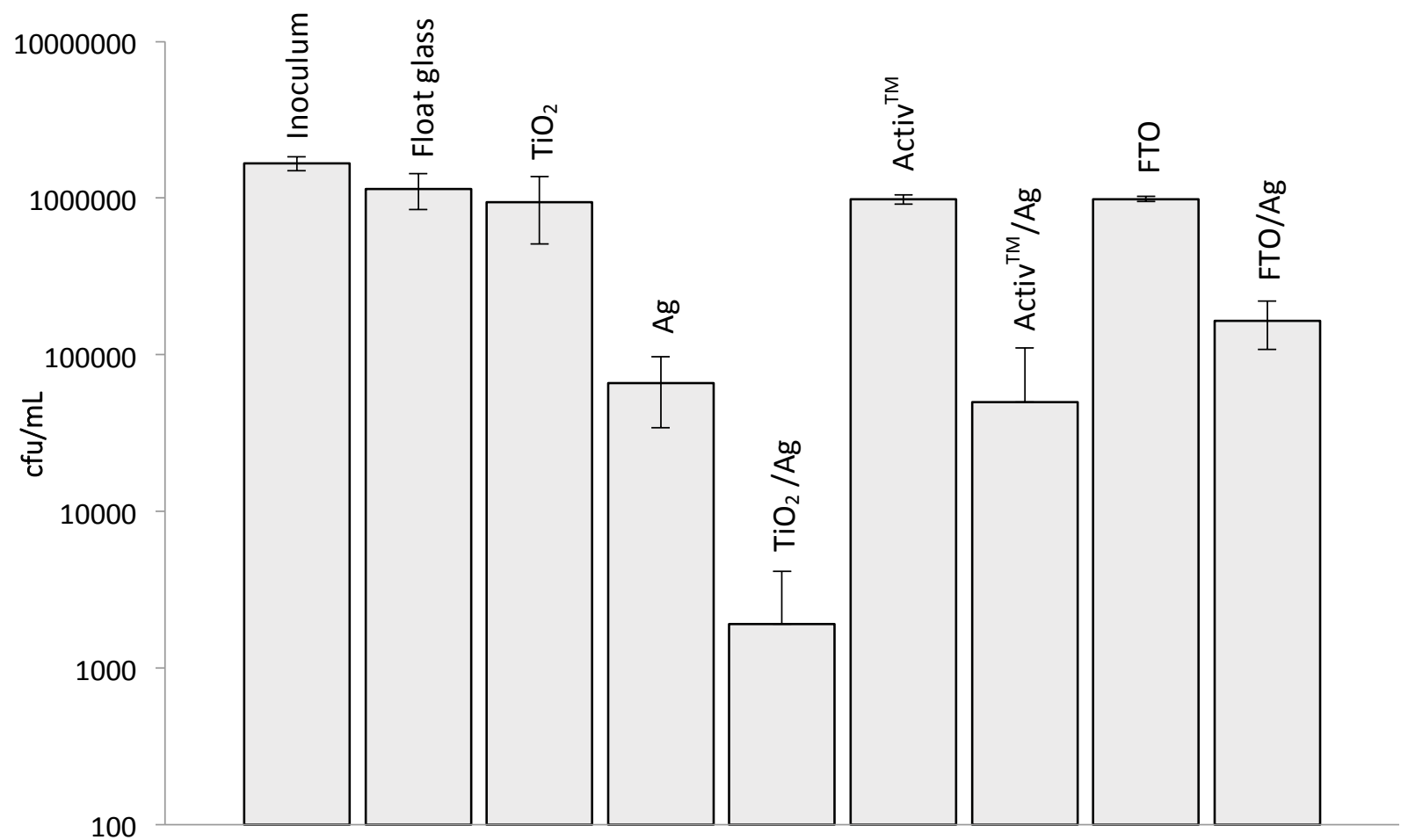

Fig. 5. Viable counts of $E$. coli after incubation on glass substrates incubated at $20^{\circ} \mathrm{C}$ in the dark for 6 hours.

Fig. 6(a) illustrates the antibacterial activity of the samples against E. coli after $365 \mathrm{~nm}$ UV light exposure for 6 hours. Activ ${ }^{\mathrm{TM}}$, Activ ${ }^{\mathrm{TM}} / \mathrm{Ag}, \mathrm{FTO}$ and FTO/Ag all achieved complete kill after 6 hours with bacterial numbers reduced to below the detection limit (data not shown). Float glass demonstrated $\sim 1 \log$ reduction in bacterial numbers and the addition of $\mathrm{TiO}_{2}$ increased this activity 
to $\sim 2$ log. However, the greatest reduction in bacterial numbers was achieved with $\mathrm{Ag}$ and $\mathrm{TiO}_{2} / \mathrm{Ag}$ films ( $\geq 4 \log ; P=0.001$ ). Fig $6(b)$ shows the antibacterial activity of the samples after only 2 hours of light exposure. None of the control samples showed any significant activity. Both $\mathrm{Ag}$ and $\mathrm{Activ}^{\mathrm{TM}} / \mathrm{Ag}$ films achieved $\sim 1$ log kill of E. coli, whereas $\mathrm{TiO}_{2} / \mathrm{Ag}$ and $\mathrm{FTO} / \mathrm{Ag}$ films demonstrated potent antibacterial activity within only 2 hours of UVA light exposure $(\geq 4 \log ; P=0.001)$. The antibacterial activity of the $\mathrm{TiO}_{2} / \mathrm{Ag}$ and $\mathrm{FTO} / \mathrm{Ag}$ films were also examined after shorter periods of time; both achieved $99.9 \%$ kill of $E$. coli within 60 minutes and a $33.3 \%$ reduction after only 30 minutes of UVA irradiation $(P=0.001)$ (data not shown). 


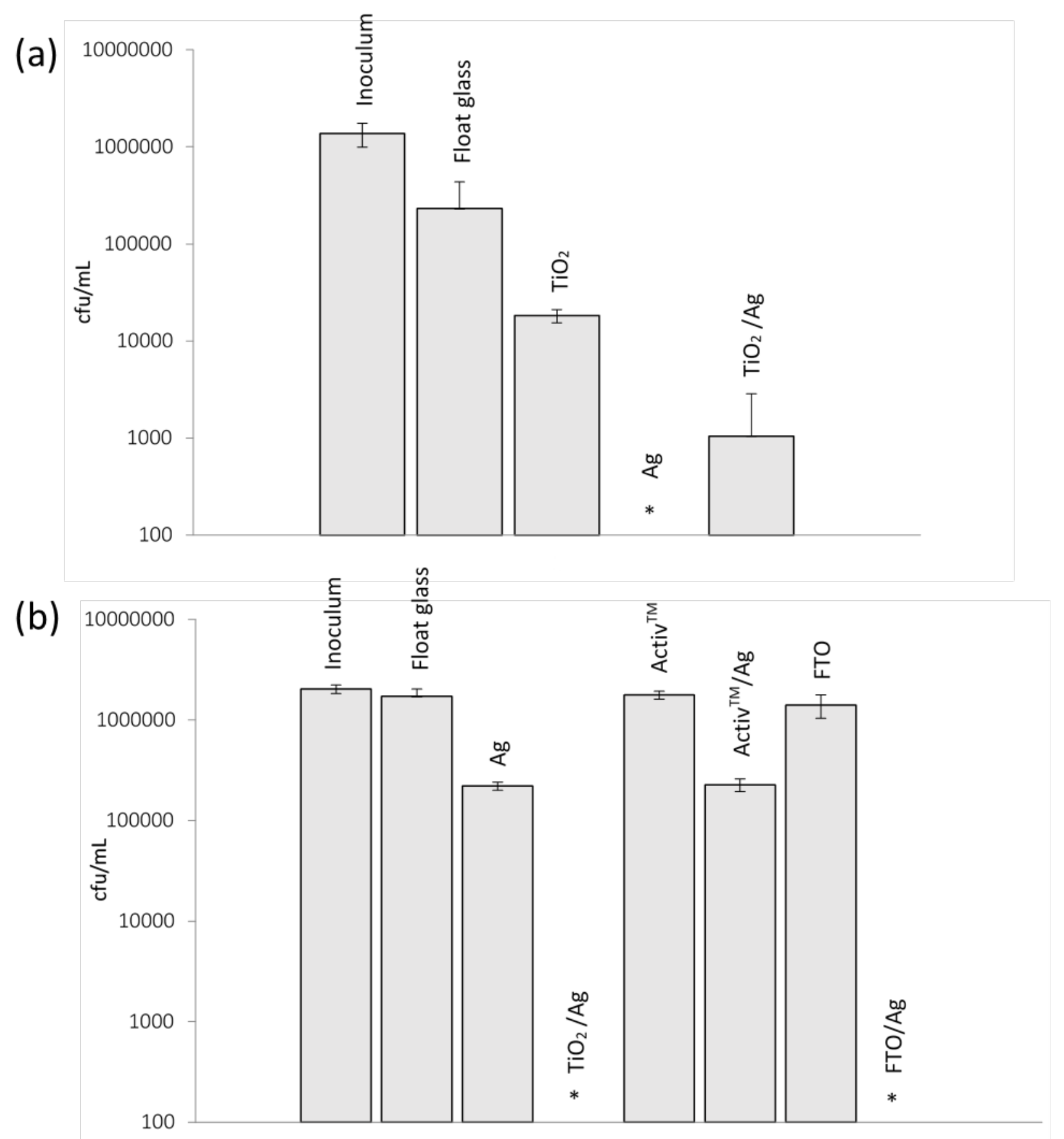

Fig. 6. Viable counts of $E$. coli after incubation on various glass substrates exposed to a $365 \mathrm{~nm}$ UV light source for (a) 6 hours and (b) 2 hours. The antibacterial activity was measured at a distance of $16 \mathrm{~cm}$ from the samples with an average light intensity of $0.65 \pm 0.23 \mathrm{~mW} \mathrm{~cm}^{-2} .{ }^{*}$ indicates that the bacterial numbers were reduced to below the detection limit of $100 \mathrm{cfu} / \mathrm{mL}$. 
Table 1. Summary of the antibacterial activity of various glass substrates films against $E$. coli after 2 hours and 6 hours of $365 \mathrm{~nm}$ UV radiation and in the dark. ${ }^{a}$ indicates that the sample also showed complete kill within 60 minutes of UVA exposure. $\mathrm{TiO}_{2}, \mathrm{Ag}$ and $\mathrm{TiO}_{2} / \mathrm{Ag}$ were deposited on float glass.

\begin{tabular}{|c|c|c|c|c|}
\hline \multirow[b]{3}{*}{ Sample } & \multicolumn{4}{|c|}{ Antibacterial activity against $E$. coli } \\
\hline & \multicolumn{2}{|l|}{ Dark } & \multicolumn{2}{|c|}{365 nm UV Light } \\
\hline & $2 \mathrm{hr}$ & $6 \mathrm{hr}$ & $2 \mathrm{hr}$ & $6 \mathrm{hr}$ \\
\hline Float glass & no kill & no kill & no kill & $1 \log$ \\
\hline $\mathrm{TiO}_{2}$ & no kill & no kill & no kill & $2 \log$ \\
\hline $\mathrm{Ag}$ & no kill & $1.5 \log$ & $1 \log$ & $\geq 4 \log$ \\
\hline $\mathrm{TiO}_{2} / \mathrm{Ag}$ & $1.5 \log$ & $3 \log$ & $\geq 4 \log ^{a}$ & $\geq 4 \log$ \\
\hline $\operatorname{Activ}^{\mathrm{TM}}$ & no kill & no kill & no kill & $\geq 4 \log$ \\
\hline $\operatorname{Activ}^{\top M} / \mathrm{Ag}$ & no kill & $1.5 \log$ & $1 \log$ & $\geq 4 \log$ \\
\hline FTO & no kill & no kill & no kill & $\geq 4 \log$ \\
\hline FTO/Ag & no kill & $1 \log$ & $\geq 4 \log ^{a}$ & $\geq 4 \log$ \\
\hline
\end{tabular}

Fig. 7 illustrates the bactericidal activity against $S$. aureus when exposed to the various samples in the dark for 4 hours. Float glass, Activ ${ }^{\mathrm{TM}}$ and FTO did not show any significant bacterial kill, however, $\mathrm{TiO}_{2}$, Activ $^{\mathrm{TM}} / \mathrm{Ag}$ and FTO/Ag caused a reduction in bacterial numbers of $\sim 0.5 \mathrm{log}$. Ag-deposited float produced $\sim 1 \log$ reduction of $S$. aureus and the combination of $\mathrm{TiO}_{2}$ and $\mathrm{Ag}$ on float glass resulted in the greatest kill of $S$. aureus within only 4 hours in the dark $(\sim 2.5 \log ; \mathrm{P}=0.001)$. Furthermore, FTO/Ag caused $\sim 1$ log reduction in bacterial numbers and $\mathrm{Activ}^{\mathrm{TM}} / \mathrm{Ag}$ caused $\sim 1.5$ reduction of $S$. aureus $(P=0.001)$. These results illustrate the enhancement of antibacterial activity when $\mathrm{TiO}_{2}$ and $\mathrm{Ag}$ are combined compared to depositing $\mathrm{TiO}_{2}$ or $\mathrm{Ag}$ alone, correlating with the results presented in Fig. 5 against E. coli.

Fig. 8 shows the antibacterial activity of the samples when tested against $S$. aureus after 2 hours of $365 \mathrm{~nm}$ UV light exposure. Float glass alone did not display significant kill of the bacteria and the addition of $\mathrm{TiO}_{2}$ showed no enhancement (data not shown). However, Ag-deposited float achieved 99.9\% kill of $S$. aureus within only 2 hours of UVA light exposure $(P=0.001)$. In addition to this, $\mathrm{TiO}_{2} / \mathrm{Ag}$ caused a reduction of bacterial numbers to below the detection limit $(\geq 4$ log; $\mathrm{P}=0.001$ ). Activ $^{\mathrm{TM}}$ did not show significant reduction of $S$. aureus, but Activ ${ }^{\mathrm{TM}} / \mathrm{Ag}$ also reduced numbers of $S$. aureus to below the detection limit $(P=0.001)$. Furthermore, FTO alone induced $\sim 1$ log reduction in bacterial numbers and the addition of Ag on FTO glass increased the kill to $\geq 4 \log$ within only 2 hours of UVA exposure. The antibacterial activity of $\mathrm{TiO}_{2} / \mathrm{Ag}, \mathrm{Activ}^{\mathrm{TM}} / \mathrm{Ag}$ and FTO/Ag were tested further at shorter light exposure times. We found that $\operatorname{Activ}^{\mathrm{TM}} / \mathrm{Ag}$ caused a $66.6 \%$ reduction of bacterial numbers within 60 minutes and $\mathrm{TiO}_{2} / \mathrm{Ag}$ displayed a $66.6 \%$ reduction of $S$. aureus in 30 minutes and complete kill within 60 minutes of UVA radiation $(P=0.001)$. Remarkably, FTO/Ag 
produced the most significant result, reducing $99.9 \%$ of $S$. aureus within only 15 minutes of UVA exposure (data not shown).

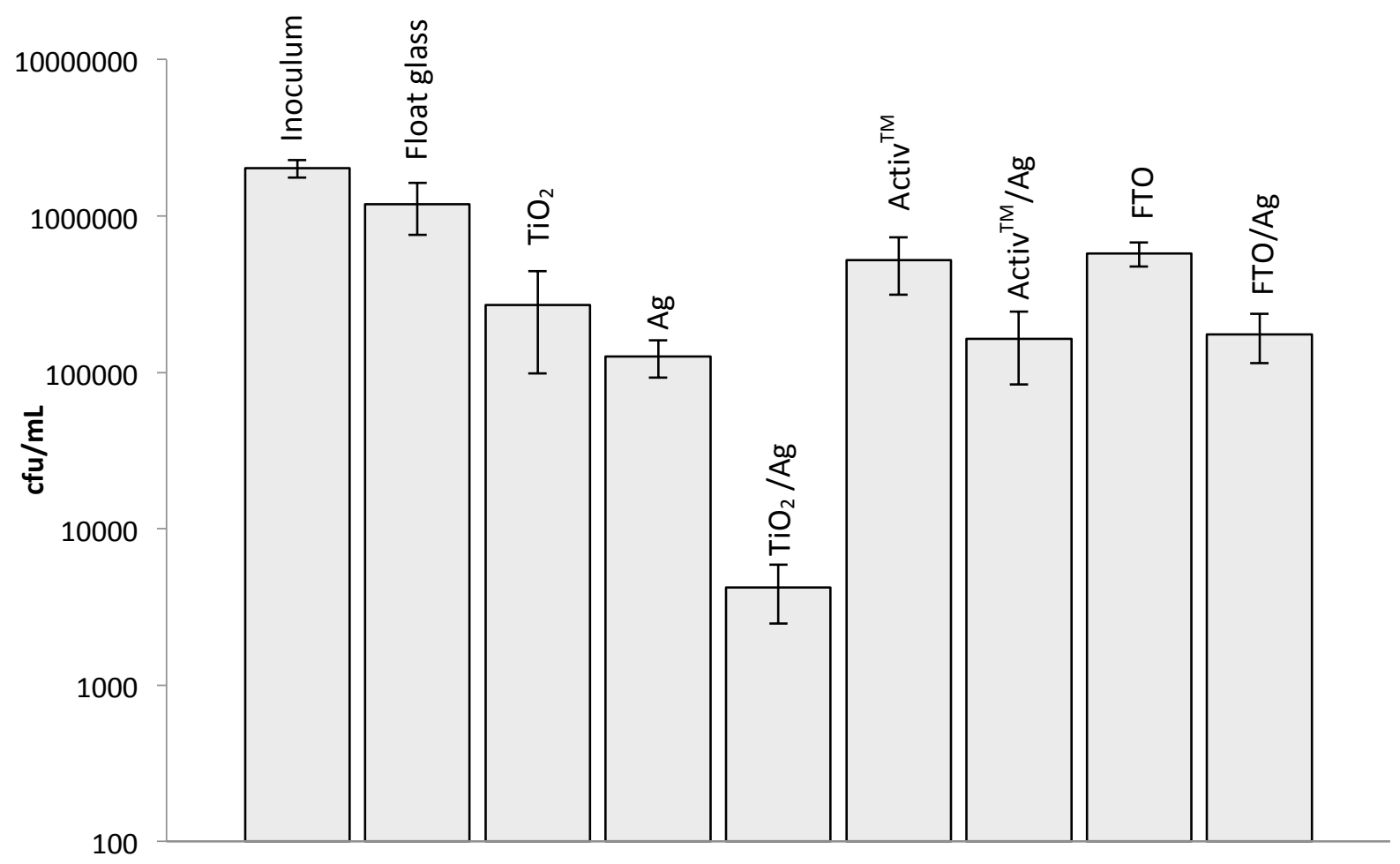

Fig. 7. Viable counts of $S$. aureus after incubation on glass substrates incubated at $20^{\circ} \mathrm{C}$ in the dark for 4 hours. 


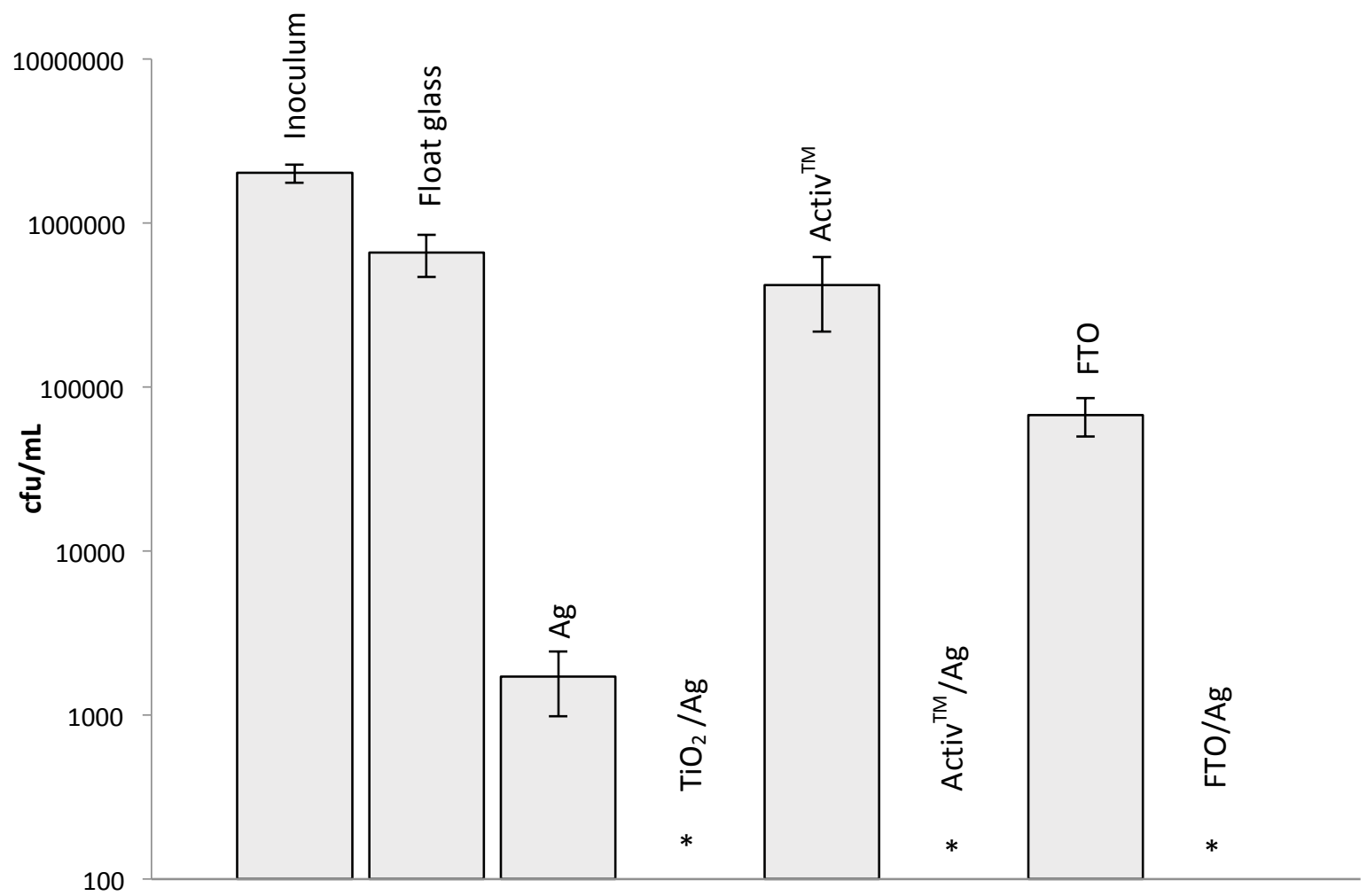

Fig. 8. Viable counts of $S$. aureus after incubation on various glass substrates exposed to a $365 \mathrm{~nm}$ UV light source for 2 hours. The antibacterial activity was measured at a distance of $16 \mathrm{~cm}$ from the samples with an average light intensity of $0.65 \pm 0.23 \mathrm{~mW} \mathrm{~cm}^{-2}$. * indicates that the bacterial numbers were reduced to below the detection limit of $100 \mathrm{cfu} / \mathrm{mL}$.

Table 2. Summary of the antibacterial activity of various glass substrates films against $S$. aureus after 2 hours and 4 hours of $365 \mathrm{~nm}$ UV radiation and in the dark. ${ }^{\mathrm{a}, \mathrm{b}}$ indicates that the sample also showed complete kill within 60 and 15 minutes, respectively, of UVA exposure. $\mathrm{TiO}_{2}$, $\mathrm{Ag}$ and $\mathrm{TiO}_{2} / \mathrm{Ag}$ were deposited on float glass.

\begin{tabular}{|c|c|c|c|c|}
\hline \multirow[b]{3}{*}{ Sample } & \multicolumn{4}{|c|}{ Antibacterial activity against $S$. aureus } \\
\hline & \multicolumn{2}{|l|}{ Dark } & \multicolumn{2}{|c|}{365 nm UV Light } \\
\hline & $2 \mathrm{hr}$ & $4 \mathrm{hr}$ & $2 \mathrm{hr}$ & $4 \mathrm{hr}$ \\
\hline Float glass & no kill & no kill & no kill & $2 \log$ \\
\hline $\mathrm{TiO}_{2}$ & no kill & $0.5 \log$ & no kill & $2 \log$ \\
\hline $\mathrm{Ag}$ & no kill & $1 \log$ & $3 \log$ & $\geq 4 \log$ \\
\hline $\mathrm{TiO}_{2} / \mathrm{Ag}$ & $2 \log$ & $2.5 \log$ & $\geq 4 \log ^{a}$ & $\geq 4 \log$ \\
\hline Activ $^{\mathrm{TM}}$ & no kill & no kill & no kill & $\geq 4 \log$ \\
\hline $\operatorname{Activ}^{T M} / \mathrm{Ag}$ & no kill & $0.5 \log$ & $\geq 4 \log$ & $\geq 4 \log$ \\
\hline FTO & no kill & no kill & $1 \log$ & $\geq 4 \log$ \\
\hline FTO/Ag & no kill & $0.5 \log$ & $\geq 4 \log ^{b}$ & $\geq 4 \log$ \\
\hline
\end{tabular}


In this investigation, Ag was deposited onto four different substrates and the antibacterial activity of the materials against $E$. coli and S. aureus was compared (summarised in Table 1 and 2). It was clear that there was a large increase in bactericidal activity against both bacteria when Ag was combined with $\mathrm{TiO}_{2}$ after both UVA light exposure and in the dark. Both the $\mathrm{Ag}$ and $\mathrm{TiO}_{2} / \mathrm{Ag}$ films achieved bactericidal activity against $E$. coli within 6 hours of UVA exposure, but after 2 hours of UVA radiation and in the dark, the $\mathrm{TiO}_{2} / \mathrm{Ag}$ film proved to be more effective. The same trend was demonstrated with $\mathrm{Ag}$ and $\mathrm{TiO}_{2} / \mathrm{Ag}$ against $\mathrm{S}$. aureus, as $\mathrm{TiO}_{2} / \mathrm{Ag}$ was more effective at 2 hours than $\mathrm{Ag}$ alone. This suggests that there is a synergistic enhancement when $\mathrm{TiO}_{2}$ and $\mathrm{Ag}$ are combined. The $\mathrm{Ag}$ nanoparticles could be enhancing the photocatalytic properties of $\mathrm{TiO}_{2}$ by promoting the formation of $\cdot \mathrm{OH}$ and $\mathrm{O}_{2}{ }^{-}$radicals with UVA irradiation. In addition to this, the effective kill of $\mathrm{Ag}$ alone under UVA light and not the dark suggests a photogenerated release of $\mathrm{Ag}$ ions into the bacteria. Two possible mechanisms could be operating which allow the silver ions to cause denaturisation of proteins in the bacterial cell wall and inhibit bacterial growth. ${ }^{33} \mathrm{Ag}$ ions could participate in catalytic oxidation reactions between $\mathrm{O}_{2}$ and hydrogen atoms of thiol groups to produce disulphide bonds, leading to the blocking of respiration and bacterial cell death. ${ }^{34}$ Another mechanism of $\mathrm{Ag}$ is the production of free radicals that induce oxidative damage of the cell membranes in bacteria. ${ }^{35}$

As summarised in Table 1 and 2, we see that there is a discrepancy between the bactericidal effects of the films against Gram-positive and Gram-negative bacteria, which is most likely due to their differences in cell wall structures. ${ }^{36}$ Gram-positive bacteria have a single thick peptidoglycan layer whereas Gram-negative bacteria have a thinner peptidoglycan layer with an inner and outer cell membrane, ${ }^{37}$ proving to be less susceptible than Gram-positive bacteria. ${ }^{38-41}$ It should be acknowledged that our study has limitations in that only laboratory strains, which are in effect domesticated, were tested. Future work should examine the activity of these materials against wild strains of multidrug-resistant nosocomial pathogens.

We see that the $\mathrm{TiO}_{2} / \mathrm{Ag}$ film achieves increased kill of E.coli and S. aureus compared to the Activ ${ }^{\mathrm{TM}} / \mathrm{Ag}$ film, which already has a thin layer of $\mathrm{TiO}_{2}$ on the surface of the glass. It is tempting to speculate that the greater thickness of the home-grown $\mathrm{TiO}_{2}$ film could account for this difference in the levels of kill achieved (Table 1 and 2). However, it is likely that the difference could be related to the size distribution of the Ag nanoparticles. As shown in Fig. 4, there is a higher concentration of $\mathrm{Ag}$ nanoparticles on the $\mathrm{TiO}_{2} / \mathrm{Ag}$ surface compared to $\mathrm{Activ}^{\mathrm{TM}} / \mathrm{Ag}$ and they are also smaller in size, giving rise to a greater surface area for bacterial-Ag interactions. This also correlates to the absorbance values of $\mathrm{Ag}$ obtained from UV-vis data, as there is a higher absorbance value for $\mathrm{TiO}_{2} / \mathrm{Ag}$ than the Activ $^{\mathrm{TM}} /$ Ag surface. 
Both the $\mathrm{TiO}_{2} / \mathrm{Ag}$ and $\mathrm{FTO} / \mathrm{Ag}$ films achieved rapid bacterial kill ( 33.3\%) within 30 minutes of UVA exposure against $E$. coli. Activ ${ }^{\mathrm{TM}} / \mathrm{Ag}$ and $\mathrm{TiO}_{2} / \mathrm{Ag}$ were highly effective at reducing the numbers of $S$. aureus by $66.6 \%$ and $99.9 \%$ within 60 minutes, respectively. Our most encouraging result was demonstrated by FTO/Ag, causing complete kill of $S$. aureus within only 15 minutes of UVA radiation. The bactericidal enhancement displayed by FTO compared with Activ ${ }^{\mathrm{TM}}$ against both bacteria could suggest that the biocidal properties associated with tin oxide ${ }^{42}$ on FTO is causing a bactericidal effect that is more effective than $\mathrm{TiO}_{2}$ on Activ ${ }^{\mathrm{TM}}$ glass. In the dark, the inherent antibacterial properties of $\mathrm{TiO}_{2} / \mathrm{Ag}$ are far more effective than any other film against both bacteria. This is promising for hospital environments that do not have optimal lighting, as within 6 hours we achieved a 99.9\% reduction in the numbers of $E$. coli and within 4 hours $99.9 \%$ kill of S. aureus. Activ ${ }^{\mathrm{TM}} / \mathrm{Ag}$ and $\mathrm{Ag}$ on float reduced $E$. coli numbers by $50 \%$ in the dark, demonstrating that Activ $^{\top M}$ glass itself does not possess antibacterial properties.

\section{Conclusion}

In this paper we have synthesised crystalline silver films consisting of silver nanoparticles. Films were deposited in an in-house built AACVD rig using easy-to-handle precursors at a relatively low temperature. We report the structural, optical and photocatalytic properties of $\mathrm{TiO}_{2}$ and $\mathrm{TiO}_{2} / \mathrm{Ag}$ films as potential antibacterial surfaces in healthcare environments. $\mathrm{TiO}_{2} / \mathrm{Ag}$ films reduced the numbers of $E$. coli by $99.9 \%$ within 6 hours in the dark, and $\mathrm{TiO}_{2} / \mathrm{Ag}$ and $\mathrm{FTO} / \mathrm{Ag}$ exhibited potent antimicrobial activity against the bacteria after only 60 minutes of UVA irradiation. $\mathrm{TiO}_{2} / \mathrm{Ag}$ was even more effective at reducing the number of $S$. aureus in the dark ( $99.9 \%$ within 4 hours), but FTO/Ag demonstrated the fastest bactericidal activity by achieving $99.9 \%$ kill of $S$. aureus within only 15 minutes of UVA exposure. This is the first time, to our knowledge, that Ag has been deposited onto FTO glass and demonstrated such potent antibacterial activity against both Gram-negative and Gram-positive bacterium. Given the current problems in hospitals with multi-drug resistant Gramnegative bacteria our data suggests that these films may be useful in reducing the load of bacteria on hospital surfaces which may in turn lead to a decrease in the spread of HAls. We conclude that the kill of bacteria on Ag films are substrate specific.

(1) Roberts, R. R.; Scott, R. D.; Hota, B.; Kampe, L. M.; Abbasi, F.; Schabowski, S.; Ahmad, I.; Ciavarella, G. G.; Cordell, R.; Solomon, S. L.; Hagtvedt, R.; Weinstein, R. A., Costs Attributable to Healthcare-Acquired Infection in Hospitalized Adults and a Comparison of Economic Methods. Med. Care 2010, 48, 1026-1035. 
(2) Ducel, G.; Fabry, J.; Nicolle, L., Prevention of hospital-acquired infections : a practical guide -. Geneva, Switzerland: World Health Organization: 2002.

(3) Larsen, J.; David, M. Z.; Vos, M. C.; Coombs, G. W.; Grundmann, H.; Harbarth, S.; Voss, A.; Skov, R. L., Preventing the Introduction of Meticillin-Resistant Staphylococcus Aureus into Hospitals. J. Glob. Antimicrob. Resist. 2014, 2, 260-268.

(4) Partridge, S. R., Resistance Mechanisms in Enterobacteriaceae. Pathology 2015, 47, 276-284.

(5) Loveday, H. P.; Wilson, J. A.; Pratt, R. J.; Golsorkhi, M.; Tingle, A.; Bak, A.; Browne, J.; Prieto, J.; Wilcox, M., epic3: National Evidence-Based Guidelines for Preventing Healthcare-Associated Infections in NHS Hospitals in England. J. Hosp. Infect. 2014, 86, Supplement 1, S1-S70.

(6) Perni, S.; Prokopovich, P.; Pratten, J.; Parkin, I. P.; Wilson, M., Nanoparticles: their Potential use in Antibacterial Photodynamic Therapy. Photoch. Photobio. Sci. 2011, 10, 712-720.

(7) Dunnill, C. W.; Ansari, Z.; Kafizas, A.; Perni, S.; Morgan, D. J.; Wilson, M.; Parkin, I. P., Visible Light Photocatalysts-N-doped TiO2 by Sol-Gel, Enhanced with Surface Bound Silver Nanoparticle Islands. J. Mater. Chem. 2011, 21, 11854-11861.

(8) Perni, S.; Piccirillo, C.; Kafizas, A.; Uppal, M.; Pratten, J.; Wilson, M.; Parkin, I., Antibacterial Activity of Light-Activated Silicone Containing Methylene Blue and Gold Nanoparticles of Different Sizes. J Clust Sci 2010, 21, 427-438.

(9) Yuan, Z.; Dryden, N. H.; Vittal, J. J.; Puddephatt, R. J., Chemical Vapor Deposition of Silver. Chem. Mater. 1995, 7, 1696-1702.

(10) Edwards, D. A.; Mahon, M. F.; Molloy, K. C.; Ogrodnik, V., Aerosol-Assisted Chemical Vapour Deposition of Silver Films from Adducts of Functionalised Silver Carboxylates. J. Mater. Chem. 2003, 13, 563-570.

(11) Franci, G.; Falanga, A.; Galdiero, S.; Palomba, L.; Rai, M.; Morelli, G.; Galdiero, M., Silver Nanoparticles as Potential Antibacterial Agents. Molecules 2015, 20, 8856-8874.

(12) Gavanji, S., The Effects of Silver Nano Particles on Microorganisms: A review. App. Sci. Report. 2013, 1, 50-56.

(13) Soo-Hwan, K., Lee, H-S., Ryu, D-S., Choi, S-J. and Lee, D-S, Antibacterial Activity of SilverNanoparticles against Staphylococcus Aureus and Escherichia Coli. Korean J. Microbiol. Biotechnol. 2011, 39, 77-85.

(14) Hansen, B. N.; Hybertson, B. M.; Barkley, R. M.; Sievers, R. E., Supercritical Fluid TransportChemical Deposition of Films. Chem. Mater. 1992, 4, 749-752.

(15) Gysling, H. J.; Wernberg, A. A.; Blanton, T. N., Molecular Design of Single-Source Precursors for 3-6 Semiconductor Films: Control of Phase and Stoichiometry in Indium Selenide (InxSey) Films Deposited by a Spray MOCVD Process using Single-Source Reagents. Chem. Mater. 1992, 4, 900-905.

(16) Xu, C., Hampden-Smith, M. J. and Kodas, T. T., Aerosol-Assisted Chemical Vapour Deposition (AACVD) of Silver, Palladium and Metal Alloy (Ag1-xPdx, Ag1-xCux, Pd1-xCux) Films Adv. Mater. 1994, 6, 746-748.

(17) Edwards, D. A.; Harker, R. M.; Mahon, M. F.; Molloy, K. C., Aerosol-Assisted Chemical Vapour Deposition (AACVD) of Silver Films from Triorganophosphine Adducts of Silver Carboxylates, including the Structure of $[\mathrm{Ag}(\mathrm{O} 2 \mathrm{CC} 3 \mathrm{~F} 7)(\mathrm{PPh} 3) 2]$. Inorg. Chim. Acta. 2002, 328, 134-146.

(18) Edwards, D. A.; Harker, R. M.; Mahon, M. F.; Molloy, K. C., Aerosol-Assisted Chemical Vapour Deposition (AACVD) of Silver Films from Triphenylphosphine Adducts of Silver $\beta$-diketonates and $\beta$ diketoiminates, including the Structure of $[\mathrm{Ag}(\mathrm{hfac})(\mathrm{PPh} 3)]$. J. Mater. Chem. 1999, 9, 1771-1780.

(19) Ponja, S. D.; Sathasivam, S.; Parkin, I. P.; Carmalt, C. J., Transparent Conductive Aluminium and Fluorine Co-doped Zinc Oxide Films via Aerosol Assisted Chemical Vapour Deposition. RSC Adv. 2014, 4, 49723-49728.

(20) Knapp, C. E.; Carmalt, C. J., Solution Based CVD of Main Group Materials. Chemical Society Reviews 2016.

(21) Sathasivam, S.; Arnepalli, R. R.; Kumar, B.; Singh, K. K.; Visser, R. J.; Blackman, C. S.; Carmalt, C. J., Solution Processing of GaAs Thin Films for Photovoltaic Applications. Chem. Mater. 2014, 26, 4419-4424. 
(22) Ponja, S.; Sathasivam, S.; Chadwick, N.; Kafizas, A.; Bawaked, S. M.; Obaid, A. Y.; Al-Thabaiti, S.; Basahel, S. N.; Parkin, I. P.; Carmalt, C. J., Aerosol Assisted Chemical Vapour Deposition of Hydrophobic TiO2-SnO2 Composite Film with Novel Microstructure and Enhanced Photocatalytic Activity. J. Mater. Chem. A 2013, 1, 6271-6278

(23) Bhachu, D. S.; Scanlon, D. O.; Sankar, G.; Veal, T. D.; Egdell, R. G.; Cibin, G.; Dent, A. J.; Knapp, C. E.; Carmalt, C. J.; Parkin, I. P., Origin of High Mobility in Molybdenum-Doped Indium Oxide. Chem. Mater. 2015, 27, 2788-2796.

(24) Romero, L.; Piccirillo, C.; Castro, P. M. L.; Bowman, C.; Warwick, M. E. A.; Binions, R., Titanium Dioxide Thin Films Deposited by Electric Field-Assisted CVD: Effect on Antimicrobial and Photocatalytic Properties**. Chem. Vap. Deposition 2015, 21, 63-70.

(25) Chew, C.; Bishop, P.; Salcianu, C.; Carmalt, C. J.; Parkin, I. P., Aerosol-Assisted Deposition of Gold Nanoparticle-Tin Dioxide Composite Films. RSC Adv. 2014, 4 (25), 13182-13190.

(26) Qazi, S. J. S.; Rennie, A. R.; Cockcroft, J. K.; Vickers, M., Use of Wide-Angle X-ray Diffraction to Measure Shape and Size of Dispersed Colloidal Particles. J. Colloid Interface Sci. 2009, 338, 105-110.

(27) Spreadborough, J.; Christian, J. W., High-Temperature X-ray Diffractometer. J. Sci. Instrum. 1959, $36,116$.

(28) M. Horn, C. F. S., E. P. Meagher, Zeitschrift fuer Kristallographie, Kristallgeometrie, Kristallphysik, Kristallchemie 1972, 136, 273-281.

(29) Gunnar, S., ESCA Studies of Ag, Ag2O and Ago. Acta. Chem. Scand. 1973, 27, 2623-2633.

(30) Crist, B. V., Handbook of Monochromatic XPS Spectra, The Elements of Native Oxides. XPS International, LLC: California 94040 USA, 1999; Vol. 1, p 548.

(31) Panneerselvam, A.; Malik, M. A.; O'Brien, P.; Helliwell, M., The Aerosol-Assisted CVD of Silver Films from Single-Source Precursors. Chem. Vap. Deposition 2009, 15, 57-63.

(32) Panneerselvam, A.; Malik, M. A.; O'Brien, P.; Raftery, J., The CVD of Silver Sulfide and Silver Thin Films from a Homoleptic Crystalline Single-Source Precursor. J. Mater. Chem. 2008, 18, 3264-3269.

(33) McDonnell, G.; Russell, A. D., Antiseptics and Disinfectants: Activity, Action, and Resistance. Clin. Microbiol. Rev. 1999, 12, 147-179.

(34) Jung, W. K.; Koo, H. C.; Kim, K. W.; Shin, S.; Kim, S. H.; Park, Y. H., Antibacterial Activity and Mechanism of Action of the Silver Ion in Staphylococcus Aureus and Escherichia Coli. Appl. Environ. Microb. 2008, 74, 2171-2178.

(35) Nguyen, V.; Ishihara, M.; Kinoda, J.; Hattori, H.; Nakamura, S.; Ono, T.; Miyahira, Y.; Matsui, T., Development of Antimicrobial Biomaterials produced from Chitin-Nanofiber Sheet/Silver Nanoparticle Composites. J. Nanobiotechnol. 2014, 12, 1-9.

(36) Noimark, S.; Bovis, M.; MacRobert, A. J.; Correia, A.; Allan, E.; Wilson, M.; Parkin, I. P., Photobactericidal polymers; the Incorporation of Crystal Violet and Nanogold into Medical Grade Silicone. RSC Adv. 2013, 3, 18383-18394.

(37) Noimark, S.; Weiner, J.; Noor, N.; Allan, E.; Williams, C. K.; Shaffer, M. S. P.; Parkin, I. P., DualMechanism Antimicrobial Polymer-ZnO Nanoparticle and Crystal Violet-Encapsulated Silicone. Adv. Funct. Mater. 2015, 25, 1367-1373.

(38) Sehmi, S. K.; Noimark, S.; Bear, J. C.; Peveler, W. J.; Bovis, M.; Allan, E.; MacRobert, A. J.; Parkin, I. P., Lethal Photosensitisation of Staphylococcus Aureus and Escherichia Coli using Crystal Violet and Zinc Oxide-Encapsulated Polyurethane. J. Mater. Chem. B. 2015, 3, 6490-6500.

(39) Ozkan, E.; Allan, E.; Parkin, I. P., The Antibacterial Properties of Light-Activated Polydimethylsiloxane containing Crystal Violet. RSC Adv. 2014, 4, 51711-51715.

(40) Noimark, S.; Allan, E.; Parkin, I. P., Light-Activated Antimicrobial Surfaces with Enhanced Efficacy Induced by a Dark-Activated Mechanism. Chem. Sci. 2014, 5, 2216-2223.

(41) Sehmi, S. K.; Noimark, S.; Weiner, J.; Allan, E.; MacRobert, A. J.; Parkin, I. P., Potent Antibacterial Activity of Copper Embedded into Silicone and Polyurethane. ACS Appl. Mater. Interfaces 2015, 7, 22807-22813. 
(42) Santos, G.; Tibayan, E.; Castillon, G.; Estacio, E.; Furuya, T.; Iwamae, A.; Yamamoto, K.; Tani, M., Tin Oxide-Silver Composite Nanomaterial Coating for UV Protection and Its Bactericidal Effect on Escherichia coli (E. coli). Coatings 2014, 4, 320-328. 
Table of Contents figure

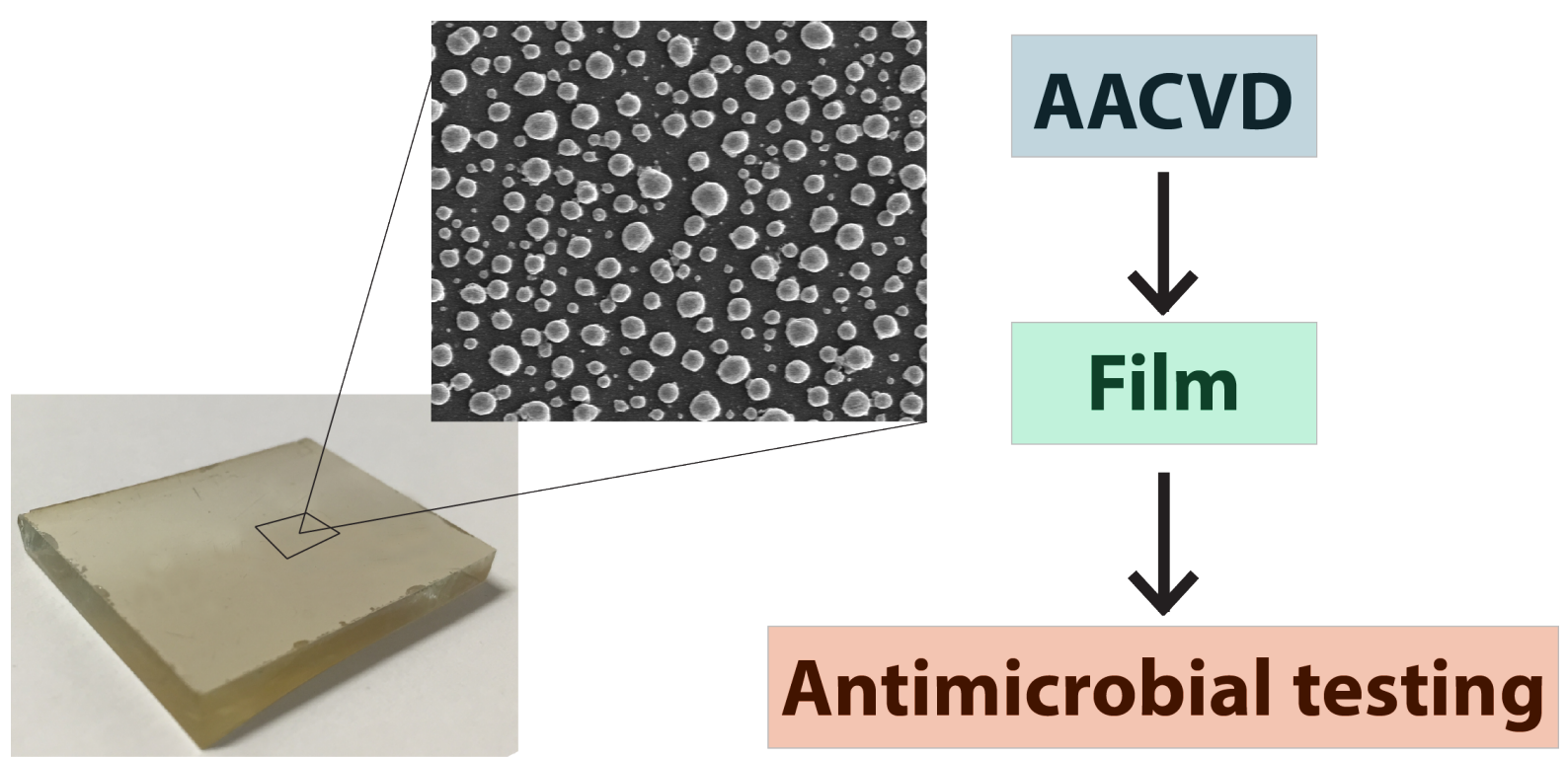

